\title{
Market integration of fish in Europe
}

Nielsen, Max; Smit, Jos; Guillen, Jordi

Published in:

Journal of Agricultural Economics

DOI:

10.1111/j.1477-9552.2008.00190.x

Publication date:

2009

Document version

Early version, also known as pre-print

Citation for published version (APA):

Nielsen, M., Smit, J., \& Guillen, J. (2009). Market integration of fish in Europe. Journal of Agricultural Economics, 60(2), 367-385. https://doi.org/10.1111/j.1477-9552.2008.00190.x 


\title{
Market integration of fish in Europe
}

\author{
Submitted January 2008 and resubmitted July 2008 to \\ Journal of Agricultural Economics
}

Max Nielsen

University of Copenhagen, Denmark

\section{Jos Smit}

LEI, the Netherlands

Jordi Guillen

University of Barcelona, Spain

Corresponding author Max Nielsen is associate professor at the Institute of Food and Resource Economics, the Faculty of Life Sciences at the University of Copenhagen, Rolighedsvej 25, DK-1958 Frederiksberg C, Denmark, e-mail: max@foi.dk. Jos Smit is fisheries economist at LEI, P.O. Box 29703, 2502 LS, the Hague, the Netherlands, e-mail: Jos.Smit@wur.nl. Jordi Guillen is fisheries economist at University of Barcelona, Av. Diagonal 690, ERE 310. Barcelona 08034, Spain, e-mail: jordi@gemub.com. 


\section{Market integration of fish in Europe}

Max Nielsen, Jos Smit and Jordi Guillen ${ }^{1}$

Abstract. This paper examines market integration between fish species in Europe, taking international market integration into account. Based on Juselius (2006), market integration is found both on the fresh and frozen markets. The Law of One Price is in force on the fresh market within the segments of flatfish and pelagic fish. Assuming transitivity, a loose form of market integration is identified between 13 fresh and 7 frozen fish species, and the relative prices are found fairly stable. The policy implication is that catch limitation measures implemented through the Common Fisheries Policy have limited and conditional effects on prices, owing to the large scale of the market and varying market integration. Therefore, many fishermen are not "compensated" by price increases as a result of catch limitation measures.

Key words: Price formation, market integration, cointegration, Law of One Price, weak exogeneity, common trends, driving forces.

JEL Classification Codes: C32, Q22.

\section{Introduction}

Several fish stocks in European waters are outside safe biological limits and fishing extraction is unsustainable (International Council for Exploration of the Sea 2007). As a consequence, many measures have been implemented over the last 2-3 decades to improve the condition of the stocks. Within the EU, measures are implemented through the Common Fisheries Policy. Total Allowable Catches is the main element, fixing annual quotas for the most important fish

\footnotetext{
${ }^{1}$ Corresponding author Max Nielsen is associate professor at the Institute of Food and Resource Economics, the Faculty of Life Sciences at the University of Copenhagen, Rolighedsvej 25, DK-1958 Frederiksberg C, Denmark, e-mail: max@foi.dk. Jos Smit is fisheries economist at LEI, P.O. Box 29703, 2502 LS, the Hague, the Netherlands, e-mail: Jos.Smit@wur.nl. Jordi Guillen work at the European Commission Joint Research Center, Ispra, Italy, e-mail: jordi.guillen@jrc.it.
} 
species and allocated to each member state through the 'relative stability' principle ${ }^{1}$. For some heavily fished species, recovery plans are also in place. In essence, the purpose of the measures of the recovery plans is to limit catches and protect stocks in the short run to improve long run catches. The consequence of using these measures is decreased earnings in the primary fishery in the short run, unless price increases compensate for this.

Are price increases likely as a result of catch limitations? Or, is the price of the species formed on a large integrated market consisting of many species where the effect is dissipated over several species and therefore negligible? This issue is addressed here by examining market integration between fish species on the European raw fish market, including both own-supply and imports. The basic assumption is that markets for individual species are integrated between the European countries with focus on integration between species at the European level. If the prices are integrated between fish species, EU catch limits on specific species will have limited price effects. If the markets for different fish species are separate, the effects on prices might be substantial.

Market integration analysis reveals whether prices of different goods follow each other over time and can thus be considered as being formed within the same market. Since the time series of prices appear non-stationary, as indeed is the case for most time series of prices, cointegration analysis must be used. Cointegration analyses can only be undertaken with relatively few variables, since variables are explained by their own lagged variables, and systems they therefore quickly become too large. In the present analysis, 23 fish species are subject to quotas in the EU, but it is beyond the scope of the cointegration methodology to include 23 possibly seperate prices in a single estimation. The 23 species are segmented here according to characteristics such as type of fish, colour of meat, size of fish, price level and fat content. 
Our analysis follows the now established cointegration methodology as documented in Juselius (2006). The methodology uses multivariate tests to identify non-stationary variables and bases the choice of cointegration rank mainly on the trade test $^{2}$. Finally, it makes it possible to find common driving trends and thereby identify the degree to which price variables are driven by themselves and other prices.

Knowledge of market integration could be used actively in the quota setting in the Common Fisheries Policy. Today the quota setting is mainly based on biological considerations as recommended by the International Council for Exploration of the Sea in their annual advice (ICES 2007). The economic consequences of changed quota setting might also be a concern, though the effect on prices is not part of the current policy consideration. An economic optimal fisheries policy would consider these factors. Finally, the issue is important for understanding and quantifying the impact of the external EU trade policy, e.g. with regard to antidumping complaints against Norwegian salmon ${ }^{3}$ or farmed fish supplied by third countries. Globalisation trends will undoubtedly further increase the influence of the market for EU fisheries and fish processing, in particular the markets for frozen products.

This analysis is made on the European level since earlier studies indicate that markets for individual fish species in different European countries are formed within the same market. Gordon and Hannesson (1996) identified strong integration of markets for frozen cod fillets in the UK, France and Germany. The same authors found integrated markets for frozen haddock (UK and France) and redfish (Germany and France). They also found relatively strong integration of markets for fresh cod in France, the UK and Germany. Nielsen (2005) identified strong integration of European cod markets and partially integrated saithe markets, and Nielsen (2004) found that the Law of One Price is in force between the Norwegian and Danish herring markets. The picture is fragmented since evidently only a fraction of the national markets were considered. It is also incomplete since imports into Europe were not 
included in all cases. On this basis, the present analysis is performed for the whole European market, including imports and thereby implicitly assuming that markets for all the individual species are country-wise integrated.

The first hypothesis is that the European fish markets for categories of similar species are integrated. The reason for this expectation is that earlier country-wise studies indicate integration between species showing more or less the same characteristics. Asche, Gordon and Hannesson (2004) concluded that the whitefish market (cod, haddock and saithe) in France is highly integrated and can be represented as one single species. Jaffry et al. (2000) found an integrated market for tuna, whiting and hake in Spain, but this market is, however, not integrated with salmon. The same authors indicate that the Spanish markets for whitefish (hake, cod and whiting) and pelagic fish (tuna and sardines) are separate markets.

The second hypothesis is that markets for fresh and frozen fish are not integrated. Fresh and frozen products are not expected to form part of the same markets because of distribution differences, geographical dimension of the markets, the actors involved and consumer preferences.

This paper consists of six sections. In section 2 the methodology is presented, followed by data description in section 3. In section 4 analysed product segments are identified, followed by results. Finally, in section 5 modelling and policy implications are discussed.

\section{Methodology}

According to Stigler (1969), a market is defined as "the area within which the price is determined, allowances being made for quality differences and transport costs.” If prices of different goods are determined within the same market, prices develop equally over time. Based on this definition the present paper uses econometric tests to identify integration of European first hand markets for different fish species. 
Whether the prices of different fish species are formed within the same market can be determined by testing the LOP. The LOP is fulfilled when prices of different species move closely together over time. Tests can be undertaken for stationary price series in a multivariate set-up by extending the Stigler (1969) bivariate framework and following the Ravallion (1986) $N$-market case by estimating equation 1 for, for example, four goods:

$$
\ln \left(p_{1, t}\right)=A+B \ln \left(p_{2, t}\right)+C \ln \left(p_{3, t}\right)+D \ln \left(p_{4, t}\right)+\varepsilon_{t},
$$

where $\left(p_{1, t}\right)$ is the price of Good $1,\left(p_{2, t}\right)$ is the price of Good 2, $\left(p_{3, t}\right)$ the price of Good 3, $\left(p_{4, t}\right)$ the price of Good 4 and where $B+C+D=1$ implies that the LOP is in force. The regression is only valid for stationary price series. For non-stationary price series, cointegration “is a natural extension” (Asche, Gordon and Hannesson 2004). However, regressing price series integrated of different orders may cause spurious correlations.

For price series integrated of the same first order, the Johansen cointegration rank procedure is used and a Vector Autoregressive (VAR) model in Error Correction form is formulated as given in equation 2:

$$
\Delta X_{t}=\Gamma_{1} \Delta X_{t-1}+\ldots+\Gamma_{k-1} \Delta X_{t-k+1}+\Pi X_{t-1}+\mu+\Psi D_{t}+\varepsilon_{t}
$$

where $X_{t}$ is a vector of prices and $\boldsymbol{D}_{\boldsymbol{t}}$ is a vector of other deterministic components, such as seasonal dummies and dummies for outliers. $\Gamma_{1} \ldots \Gamma_{k-1}, \Pi, \mu$ and $\Psi$ are all parameters. The matrix $\Pi$ is the long-run solution to the VAR model and contains the possible cointegrating relationship. The number of cointegrating relations in $\Pi$ is chosen on the basis of the now established cointegration methodology, as documented in Juselius (2006).

The rank of $\Pi$ determines the number of stationary linear combinations of the variables in $\boldsymbol{X}_{\boldsymbol{t}}$. If the rank is exactly the number of variables minus one, two in the case of three variables, a single integrating factor common to all the price series exists (Asche, Bremnes and Wessells 1999; Gonzales-Rivera and Helfand 2001), indicating market integration. If so, 
$\Pi$ can be decomposed into $\alpha \beta^{\prime}$ where $\alpha$ contains the adjustment coefficients and $\beta$ the cointegrating vectors. The LOP is tested by imposing restrictions on the $\beta$ matrix following Juselius (2006).

Cointegration tests and tests of the LOP are undertaken for non-stationary price series in order to determine market sizes. When the cointegration test identifies a single integrating factor that is common to all the price series, and the test of the LOP shows that the LOP is in force, the analysed goods are homogeneous, relative prices are constant and markets are closely integrated. If a single common integrating factor is identified and the LOP is rejected, markets are partially integrated and the goods are imperfect substitutes. Where cointegration tests cannot identify one common integrating factor, market integration between goods cannot be identified.

In the present paper, market integration is tested within small segments consisting of several goods. Market integration is found between goods A and B and B and C, respectively, but a reliable model with goods $\mathrm{A}$ and $\mathrm{C}$ could not be found in all cases. In that situation, a loose form of market integration is introduced where the results of the market integration tests are combined with a transitivity assumption. This implies that the markets for goods $\mathrm{A}$ and $\mathrm{C}$ are loosely integrated. Thereby, three degrees of market integration are identified: close, partial and loose.

Following the tests identifying market sizes and boundaries, tests of weak exogeneity of price series are undertaken to identify causal relationships in integrated markets, thus allowing the identification of market leaders. Weak exogeneity is tested by imposing restrictions on $\alpha$, following Juselius (2006).

Finally, common driving trends are found, thereby identifying driving forces in the systems. Where the tests of weak exogeneity identify the direction of shocks, common driving trends identify whether and to what degree a price series is driven by itself and by other price 
series in the system. Drivers are identified on the basis of a Moving Average representation, as opposed to market leaders which appear from a Vector Auto Regressive model.

\section{Data}

The domestic supply of fish for human consumption in Europe was 12.4 million tonnes in 2005, of which 10.3 Million tonnes ${ }^{4}$ originated from capture fisheries and 2.1 million tonnes from aquaculture (Eurostat 2007). The main supplier countries include Spain, Norway, Italy and Iceland. The EU-15 catches for human consumption formed 4.0 million tonnes and aquaculture production 1.2 million tonnes (2005). Import from outside the EU 15 were 4.3 million tonnes traded weight and exports 1.7 million tonnes, revealing that EU-15 is a large netimporter of fish. Thus, total supply for domestic consumption is 7.8 million tonnes, roughly corresponding to an EU-15 per capita consumption of fish of $22.4 \mathrm{~kg}$ live weight ${ }^{5}$.The main European consumer countries are located within the EU-15 and include France, Spain and Germany. Consumption consists of several species of whitefish, flatfish, pelagic fish and crustaceans. Cod, salmon, shrimps and tuna are the most important species in consumption terms. Consumption differs considerably between countries. There is a substantial trade between countries, with 1.0 million tonnes imported to the EU-15 from Norway, Iceland and the Faroe Islands, and with an additional 4,062,000 tonnes traded internally between the EU-15 countries, reflecting different endowment of fish between the European countries.

Data on the European supply of fish were obtained from the New Cronos Database (Eurostat 2007). Supply includes landings in the EU-15 countries, landings in Norway, Iceland and on the Faroe Islands, and import of raw fish to EU-15 ${ }^{6}$. Landings of all fish species subject to a Total Allowable Catches in the EU were included in the analysis ${ }^{7}$. Data were collected monthly, covering the period January 1995 through December 2005 (132 
observations) and are available in volume, value and unit price for 23 fish species. Because of data gaps, it was necessary to combine this source with the national sources for France, Ireland and the Faroe Islands. Data on aquaculture production were not available on a monthly basis. Therefore, Norwegian and British salmon exports to the EU-15 were used as proxies for salmon production in each of the two countries. The majority of Norwegian and British salmon production is exported to EU-15.

Import of raw material includes the product forms live, fresh, frozen, fresh fillets and frozen fillets, corresponding to the relevant codes under "03 Fish, crustaceans, molluscs and other aquatic invertebrates" in the harmonised system except "0305 Fish, dried, salted and smoked”. To avoid double counting, imports from EU countries, Norway, Iceland and the Faroe Islands were excluded.

Data are provided for single species separately in fresh and frozen form. An aggregate consisting of total supply (landings, aquaculture production and import) of each species is constructed in fresh and frozen form, respectively. Quantities are measured in live weight equivalents, and prices are for one kilo live weight. The data are converted into live weight in order to study supplies which consist of both whole and filleted fish. The Food and Agricultural Organisation of the United Nations (2000) official conversion factors are used where $33-50 \%$ of the whole fish is used for consumption.

Plaice is mostly landed fresh, but is included in the analysis as frozen since this species is mostly sold frozen. Freshwater fish includes mainly tilapia and catfish. Hake is an aggregate of several different hake species which cannot be separated in the landing statistics of the main supplier country, Spain. Landings of shrimp include only cold-water shrimp, where import includes all shrimp species. Summary statistics are presented in Table 1 as annual averages. [ Table 1 about here] 
Total annual supply of fresh and frozen raw fish consisted on average of 3.3 and 2.5 million tonnes, respectively. Thus, the present analysis covers $5 \%$ of the global fish supply and $45 \%$ of the European fish supply. The corresponding values are $€ 4.8$ and $€ 4.5$ billion. The supplies of fresh fish originate from mainly domestic sources where frozen fish are generally imported. The reason for this specialisation includes the presence of considerable direct transportation costs for fresh fish over long distances, and indirect costs related to value loss with freshness deteriorating when transportation of fresh fish transport lasts for several days. Self-sufficiency is high for most fresh fish where it differs between species on the frozen market. Most frozen species follow the pattern of relatively low self-sufficiency, although species like haddock, saithe, plaice, herring and mackerel are particularly self-sufficient.

\section{Product Segments}

Cointegration analysis can only be undertaken with a limited number of variables included. Therefore, the present estimations cannot be made with all 23 species at the same time. Hence, a strategy is chosen where market integration tests are undertaken with up to four species included simultaneously. Market integration is tested and, when identified, up to two additional species are included. Tests are performed separately for the fresh and frozen markets. This procedure is chosen to minimise the estimation effort, and through that obtaining detailed insight in the European fish market. This implies that market integration is tested within segments of only 5 species, or less.

Fish products are segmented according to 1) type of species (whitefish, flatfish, pelagic fish and crustaceans), 2) colour of meat (white, non-white), 3) size of fish (small, medium, large), 4) price level and 5) fat content (lean and fat) ${ }^{8}$. For each criterion, segments are formed for the 6 most important species in value terms (4 plus 2 additional species). The implication of this selection process is that blue whiting, megrim, dab and ray are not 
included in the analysis. That leaves16 fresh and 13 frozen products to be analysed, as shown in Appendix 1. A total of 162 models are estimated and of these 20 well-specified models reveal some market integration ${ }^{9}$.

Juselius (2006) introduces two principles for estimation; Specific-to-general (with variables included according to economic theory) and general-to-specific (variables selected according to statistical fit). The specific-to-general principle implies that the species are segmented according to similar characteristics. The general-to-specific is used in that all species within each set are statistically tested.

\section{Results}

Results are reported in three steps. First, well-specified models with market integration are presented. Product segments with market integration between species are identified and background tests conducted to ensure that all variables are I(1) and to avoid any misspecification. Second, tests for the LOP identifying close market integration and tests for market leaders are reported. Finally, common driving trends are identified.

\section{Identifying market integration}

In this section market integration of non-stationary, price series are identified. However, market integration of price series integrated of the first order can only be revealed in wellspecified models with a rank of the number of variables minus one. Therefore, absence of misspecification, I(2) and stationarity, as well as the presence of a rank of the number of variables minus one, must be secured before market integration can be reliably identified.

Tests for misspecification included autocorrelation, normality and autoregressive conditional heteroscedasticity (ARCH), and the conclusions of the presence and absence of 
misspecification problems were obtained at the $5 \%$ significance level ${ }^{10}$. The used tests were the multivariate LM test for the first and second order autocorrelation in the residuals, a multivariate test of normality of the Shenton-Bowman type (Dennis et al 2005), and univariate LM tests for autoregressive conditional heteroscedasticity with degrees of freedom equal to the number of lags. The presence of $\mathrm{I}(2)$ was rejected at the $5 \%$ level in all the reported results.

For well-specified models, models with a common integrating factor were sought. Models are sought with 1-4 lags, with a constant restricted to the cointegration space ${ }^{11}$, with and without eleven centred seasonal dummies, and with and without outlier dummies. Dummies for outliers were potentially introduced when the standardised residuals of an observation of a variable were larger than 3.2, following the Bonferoni criterion (Juselius 2006; Babula, Newman and Rogowsky 2006). The dummies are transitory and include a value of 1.0 for the outlier observation followed by a value of -1.0 in the following observations. All other values are zero.

In the 20 well-specified models, the rank is determined using the trace test, the characteristic roots, the significance of the $\alpha$ parameters in each cointegration vector, and the graphs of the cointegrating relations, following Juselius (2006). However, owing to space limitations only results of the trace tests are reported. The results are presented in table 2. [Table 2 about here]

Model 1 to 12 reveal partial market integration on the fresh market, model 13 to 19 on the frozen market, and model 20 between the fresh and frozen markets. The first line represents model characteristics and rank determination indicators for model 1 of fresh cod and hake prices. The model is identified with two lags, without seasonal correction and with a transitory dummy for the price of fresh cod for outliers in May 1995 and January 2000.

In the bivariate models, the trace test of the null hypothesis of the rank being two or less 
is rejected, but the null of the rank being one or less is accepted ${ }^{12}$.

In the multivariate models (3, 4 and 6 ) with three species, the trace tests point towards a rank of two. The consequence is that evidence of cointegration, and thereby of market integration, is stronger in the bivariate models than in the multivariate, although evidence exists in all the models.

Given the determined rank, the presence of unit roots was tested to ensure that all price series were within the same first order. The multivariate test for stationarity was performed with a restricted constant used according to Dennis et al. (2005). The null hypothesis is the presence of stationarity of the single variables, tested using $\chi^{2}$ tests by imposing unit rows in $\beta$. The test results are reported in Table 3. [Table 3 about here]

Stationarity is absent at the $5 \%$ level in all models since models were selected to fulfil that claim. Since all data series are non-stationary and I(2) trends are absent, all data series are integrated of the first order, confirming partial market integration between the species included in each test.

The results reveal integration between fresh and frozen markets for salmon (test 20). Integration of fresh and frozen markets for capture fish could not be identified. 12 models identified integration on fresh markets between 13 species, where 7 models identified integration of frozen markets between 7 species. On the fresh market, haddock, saithe and shrimp formed separate markets, as no relationships between these and other prices where found. On the frozen market, shrimp, freshwater fish, saithe, mackerel, salmon and swordfish formed separate markets, since relationships between these and other prices were not found. Hence, evidence is found of the fresh fish market being more integrated than the frozen. One explanation might relate to access through perishability of fresh fish and storability of frozen.

On the fresh market, hake is integrated with most other species (six), followed by sole with four, herring, mackerel and monkfish with three, cod and lemon sole with two. Most of 
the tests identify market integration within type of species (pelagic fish, flatfish and whitefish), but product segments formed on the basis of all characteristics reveal market integration. Hence, the fresh market is, in most cases, characterised by integration between similar types of fish, but integration exists between all parts of the market. Assuming transitivity, evidence of all 13 species forming part of the same integrated market exists.

On the frozen market, integration is present between cod and respectively hake, haddock and plaice. Plaice is further integrated with 4 other species. Hence, cod and, in particular, plaice prices are formed on the same market as several other species where prices of all other species are only integrated with the two. Market integration on the frozen market is determined in product segments based on all the different characteristics; type, colour, size, price and fat content. The five characteristics are of equal importance, as opposed to fresh fish where type dominates. Assuming transitivity, the 7 frozen species form part of the same market, since the prices of cod and plaice are formed within the same market and since either the price of cod or plaice is also formed within the same market as the five other species.

The results are in accordance with a priori expectations in the sense that all product segments are formed on the basis of similar characteristics. However, despite that some results seem surprising. The market for fresh salmon is integrated with anchovies, the markets for fresh herring and swordfish are integrated, and the market for frozen plaice and herring is integrated. These results can be explained by the presence of one or more similar characteristics. Additional explanations remain a matter of speculation.

\section{Testing for the Law of One Price and market leaders}

To identify whether prices are formed within the same closely integrated markets, the LOP is tested. In a closely integrated market, the prices follow each other over time and relative 
prices are constant. Market leaders are identified by testing weak exogeneity of the single price series. The results of both tests are presented in Table 4. [Table 4 about here]

At the 5\% level, the LOP cannot be rejected in 7 of the 20 models, and the markets of species included in these models are closely integrated. Markets for fresh and frozen salmon are closely integrated, presumably since the salmon market is overwhelmingly supplied by farmed fish. On the frozen market only cod and plaice prices are formed on the same closely integrated market, where close market integration is identified in 5 cases on the fresh market. This underlines the result that the fresh market is more integrated than the frozen. For the fresh fish market, integration appears mainly for flatfish and pelagic fish. Assuming transitivity, the closely integrated flatfish market consists of three species and the pelagic of four.

Table 4 further identifies market leaders by testing weak exogeneity. On the frozen market, cod, pollack, hake, monkfish and herring are weakly exogenous to plaice. That is, the price of plaice is formed on a market where other species are market leaders in all the identified models. Furthermore, haddock and hake are market leaders for cod. On the fresh market, cod, sole and monkfish are market leaders. Hake prices are formed on markets led by, e.g., cod or sole, whereas herring prices are formed on a market without market leaders.

\section{Testing for common driving trends}

Given the rank of the number of variables minus one, the driving forces of the single common trend in each of the 20 systems are identified in Table 5. In the present model with only price series included, the parameters of the long run impact matrix $C$ measure the driving forces of the price series. That is, they identify the extent to which the prices are driven by themselves and by other price series. [Table 5 about here] 
The first line shows that the system in model 1 with fresh cod and hake prices is significantly driven only by the cod prices. The high $C_{11}$ value of 0.80 measures that the cod price to a large extent is driven by itself. The price of hake is with the significant $C_{21}$ value of 0.19 only driven by the price of cod, rather than by itself ( $C_{22}$ is insignificant).

On the frozen market, the plaice price is significantly driven by cod, pollack, hake, monkfish and herring without being significantly driven by itself in any case. The effects from cod, pollack and hake are the greatest. The cod price is significantly and positively driven by haddock (0.20 in model 13$)$ and significantly and negatively by hake. The long-run cod price is also driven by shocks of its own, but the extent remains ambiguous. Model 13 indicates insignificance where model 15 shows a significant and high self-driving force (0.70). The prices of the remaining species on the frozen market are highly driven by themselves with $C_{i i}$ being 0.54 to 1.01 .

On the fresh market, cod prices are significantly driven only by themselves with high own effects. The sole price is significantly driven, mainly by itself with high own effects, but it is also significantly and positively affected by lemon sole, hake and Norway lobster. Hake prices are significantly driven by themselves with moderate own effect. Hake prices are further significantly and moderately affected by lemon sole, monkfish, cod and mackerel.

According to Table 1, salmon, cod, hake, mackerel and sole possess the largest shares of the fresh market. Therefore, the prices of cod and sole drive both themselves and the prices of other species. Hake and mackerel prices, on the other hand, seem to a larger extent driven by other species. The fresh pelagic market is closely integrated with long-run prices of the individual species, driven by themselves only to a low extent, but driven by the prices of several other species. The prices of the single flatfish species are driven by themselves to a large extent and with prices of sole and hake as additional drivers. The price of fresh cod drives itself without being affected by other species, but with an effect on hake and whiting. 


\section{Discussion}

The results of the present paper reveal that the LOP is in force within the European markets for fresh flatfish, fresh pelagic fish and between frozen cod and plaice. Partial market integration was further identified in 12 fresh and 7 frozen models. These included all 13 fresh and 7 frozen fish species. Market integration between fresh and frozen could only be found for salmon.

The results reveal loose market integration at the European level between several species, among which partial and close integration was found in some market segments. Market integration exists mostly at the fresh, but also at the frozen market. Closely integrated product segments of fresh flatfish and pelagic fish, and a partially integrated market for fresh whitefish were found. For the fresh market, segments with partial and close market integration were mainly identified for similar types of species (flatfish, pelagic fish and whitefish), but other characteristics were also of importance. At the frozen market, segments were identified on the basis of all the characteristics.

The first hypothesis (that European fish markets for categories of similar species are integrated) is true for fresh fish, and to some extent also for frozen fish. On the fresh market it is surprising that market integration between some of the major Atlantic species, e.g. haddock and saithe with cod and turbot with sole, remains unidentified.

The results further indicate that integration of the frozen fish market is low in terms of the number of species, which may not be surprising given the different characteristics and markets for specific segments of species. Frozen whitefish and shrimps are mainly imported to the EU markets. Frozen pelagic species caught by EU fishermen are mainly exported to Africa, Asia, Eastern Europe and Russia. However, it is surprising that no integration could be identified between the major frozen whitefish species which were expected to develop in 
an integrated market as indicated by the former country-wise studies of Spain and France (Jaffry et al 2000; Asche, Gordon and Hannesson 2004). This might be due to the fact that these studies analyse mainly fresh fish and that fresh fish markets in general are more integrated than frozen fish markets. One reason might also be that frozen fish are always available and therefore do not need substitutes to the same extent as fresh fish.

Finally, the results revealed no indication of integration between the markets for fresh and frozen fish other than salmon. Hence, except for salmon, the second hypothesis (that markets for fresh and frozen fish are not integrated) is true.

The results for market leaders and driving forces are summarised in Figure 1 which shows partial and close market integration between the dominant species. Market leaders based on the tests for weak exogeneity are also provided and the direction of the arrows goes from market leaders to the other species. Species with a large market share are in capital letters. The grey boxes reveal species with large market shares (> 5\% of value) which to a large extent are also self-driven (own-values in the C-matrix > 0.5). [Figure 1 about here].

Cod and sole seem to act as market leaders of the whole fresh whitefish market which is only to a limited extent is driven by the prices of other species. The prices of other whitefish will subsequently follow the trend of the cod prices. The prices of a number of other species tend to change with the sole price. The diagram suggests two EU consumer markets for fresh whitefish; the north-oriented and cod driven market for whitefish (cod and whiting) and the Southern EU market (hake, sole, monkfish and lemon sole), with sole as a main driver. Sole and cod obviously make the link between markets for these species in the north and south. The markets for fresh pelagic species were identified as strongly integrated, but without clear drivers. The main drivers for the price formation of the frozen whitefish market seem to originate from three independent sources; cod, hake and pollack (including Alaska pollack). Prices of frozen plaice are mainly driven by these species and are not driven by themselves. 
The markets for the different frozen pelagic species are, surprisingly, not found to be integrated. The explanation remains a matter of speculation, but storability and, therefore, availability might imply that substitution is not necessary.

The implications of these findings cover methodological and policy issues. On the methodological front, first, the Juselius (2006) cointegration methodology creates new and more reliable knowledge of the markets where price series are integrated of the first order. Second, it creates new structured knowledge on a multi-goods market using product segmentation. Using segments provides for additional and structured information which is otherwise impossible to obtain. Third, the identification of common driving trends reveals information in addition to market leaders, thereby determining whether the prices of the single goods are driven by themselves or other prices. Hence, the methodology reveals more information than earlier studies, and the information is obtained using a more reliable methodology than in earlier studies.

The weakness of the methodology is that cointegration analysis can only be undertaken with a limited number of variables, thereby loosing information on the complete system. The results here show market integration in systems with only 2 and 3 species, even though systems with up to 5 species were investigated. Attempts to identify systems with 4 and 5 species failed due to misspecification, the presence of stationary and I(2) variables and also on rank grounds.

The reliability of these results might be questioned since the models contain only 2 and 3 price variables. Gonzáles-Rivera and Helfand (2001) recently demonstrated that bivariate models are "inadequate for capturing the spatial dynamics of price adjustments." Furthermore, the results reveal several examples where market integration is found between species A and B, and between B and C, without finding market integration between A and C and without finding market integration in a model containing all three species. In reality, 
variables might be affected by a large number of factors which cannot all be included in cointegration analysis. An ideal study would model all 23 species simultaneously and include all factors that affect these prices, but is likely prevented in practice by data availability. However, combining statistical results on segmented data with a transitivity assumption reveals evidence of loose market integration.

The implications of the results for economic modelling are partly that fish prices must generally be considered segregated in fresh and frozen products, and partly that landings and imports in all the European countries must be analysed. The absence of integration between fresh and frozen fish markets indicate that, when modelling first hand prices of EU fish landings, it is not necessary to consider imports from outside Europe, though landings in Norway and Iceland should be included. The reason is that 93\% of the European supply of fresh fish originates from Europe (Table 1). Price models of fresh pelagic species should include all other major pelagic species, and the prices of the three main frozen whitefish species (cod, pollack and hake) could be modelled in single species systems. Plaice prices could be modelled in relation to these species and independent of own landings. The prices of frozen pelagic fish could be modelled in single species systems.

The policy implication of the finding of market integration relates to whether quota reductions implemented through the Common Fisheries Policy are followed by increasing prices, thereby "compensating” fishermen and making policy reform easier. Given the identified market integration, large price increases are in general not expected as a result of catch limitations. Catch limitation policies will not only have an effect on own prices, but will also increase other prices in the integrated system. Since the markets are large, price increases of even large quota reductions of individual stocks will be small. The smaller price effect, the more markets the species is integrated with, the closer the integration is, and the smaller the share of the European market which it supplies. 
Recovery plans are used in the Common Fisheries Policy to improve the condition of the stocks in the long-run by limiting short-term catches. The short-term implication is decreasing turnover and earnings of fishermen. Recovery plans are presently in place for North Sea cod, North Sea plaice and sole and northern hake. The short-term catch limitations of these species might cause price increases given that they possess a significant market share and that each of their markets are unlinked to other fish markets. Since the European cod market is mainly supplied by Norway and Iceland, North Sea cod delivers a small share, and a substantial price increase does not appear likely. North Sea plaice supplies a significant share of plaice in Europe, but despite that price increases are unlikely owing to the presence of market integration with several other species. North Sea sole supplies the majority of the European fresh sole market, and since sole is a market leader, prices might increase. On the other hand, the possible price increase is limited since sole markets are integrated with several other species. Hence, for individual fish species, price increases might follow from catch limitations, but for most species that is not likely.

Fishing quotas within the EU are negotiated once a year in the Council of Ministers. In these negotiations the Total Allowable Catch for all species in all waters is decided and each member state is allocated a fixed share, following the relative stability principle. The decision is based on advice from the International Council for Exploration of the Sea and the European Commission's Scientific, Technical and Economic Committee for Fisheries. The advice includes biological and, to some extent, economic aspects such as costs and earnings. Improved fisheries management from an economic point of view, however, also requires that price effects are explicitly taken into account. Given integration between species markets, price effects must be treated in a multi-species context, for example by focusing on market leaders such as fresh cod and sole. In fisheries management, price-based fisheries management is the necessary instrument to take prices into account. 
The policy implication of the absence of integration between fresh and frozen capture fish species suggests that changes of external tariffs will only have minor impact on prices obtained by the EU fishermen since they generally land fresh fish. The policy implication of the finding of a close market integration between fresh and frozen salmon is that EU import restrictions on Norwegian salmon only result in frozen salmon being imported from somewhere else. 


\section{References}

Asche, F., H. Bremnes and C. R. Wessells (1999), Product Aggregation, Market Integration and Relationships Between Prices: An Application to World Salmon Markets, American Journal of Agricultural Economics 81:568-581.

Asche, F., D. Gordon and R. Hannesson (2004), Test for Market Integration and the Law of One Price: The Market for Whitefish in France, Marine Resource Economics 19:195-210.

Babula, R. A., D. Newman and R. A. Rogowsky (2006), A Dynamic Model of U.S. SugerRelated Markets: Cointegrated Vector Autoregression Approach, Journal of Food Distribution Research, 37 (2), 35-60.

Dennis, J.G. (2005), H. Hansen, S. Johansen and K. Juselius (2005), CATS in RATS Cointegration Analysis of Time Series, version2, Estima, http://www.estima.com.

Eurostat (2007), New Cronos Database, available at http://epp.eurostat.ec.europa.eu/, accessed November 2007.

Food and Agricultural Organisation of the United Nations (2000), Conversion Factors Landed Weight to Live Weight, FAO Fisheries Circular No. 847, revision 1.

Gonzales-Rivera, G. and S. M. Helfand (2001), The Extent, Pattern, and Degree of Market Integration: A Multivariate Approach for the Brazilian Rice Market, American Journal of Agricultural Economics 83:576-592.

Gordon D.V. \& Hannesson R. (1996), On Prices of Fresh and Frozen Cod Fish in European and U.S. Markets, Marine Resource Economics, 11, 223-238.

International Council for Exploration of the Sea (2007), Report from the Advisory Committee of Fisheries Management, available at http://www.ices.dk/indexfla.asp.

Jaffry S., Taylor G., Pascoe S. \& Zabala U. (2000), Price interactions between salmon and wild-caught fish species on the Spanish market, Aquaculture Economics and Management, 4:157-167.

Johansen, S. (1996), Likelihood-Based Inference in Cointegrated Vector Autoregressive Models, Oxford, UK: Oxford University Press.

Juselius, K. (2006), The cointegrated VAR model, Methodology and applications, Oxford University Press.

Kinnucan, H. W. and Ø. Myrland (2002). The Relative Impact of the Norway-EU Salmon Agreement: A Mid-term Assessment, Journal of Agricultural Economics 53:195-220.

Nielsen, M. (2004), International market integration and demand: An analysis of the Norwegian and Danish herring market, Food Economics, 1 (3), 175-84.

Nielsen, M. (2005), Price Formation and Market Integration on the European First-hand Market for Whitefish, Marine Resource Economics 20:185-202.

Ofimer (1999), Données de commercialisation sous criées, bilan annuel 1995-98, Paris.

Ravallion, M. (1986), Testing Market Integration, American Journal of Agricultural Economics 63(1):102-109.

Statistics Faroe Islands (2006), Landing Statistics, available http://www.hagstova.fo/, accessed autumn 2006.

Statistics Iceland (2006), Landing Statistics, available http://www.verdlagsstofa.is/, accessed autumn 2006.

Stigler, G. J. (1969), The Theory of Price, London, England: MacMillan. 
TABLE 1. Total supply of fish (landings and imports) in 18 selected European countries, annual average of 1995-2006.

\begin{tabular}{|c|c|c|c|c|c|c|c|c|}
\hline & \multicolumn{4}{|c|}{ Fresh } & \multicolumn{4}{|c|}{ Frozen } \\
\hline & $\begin{array}{l}\text { Quantity } \\
\text { (tonnes) }\end{array}$ & $\begin{array}{r}\text { Value } \\
(€ \text { Million }) \\
\end{array}$ & $\begin{array}{r}\text { Price } \\
(€ / \text { kg. })\end{array}$ & $\begin{array}{l}\text { Self-suffi- } \\
\text { ciency (\%) }\end{array}$ & $\begin{array}{r}\text { Quantity } \\
\text { (tonnes) }\end{array}$ & $\begin{array}{r}\text { Value } \\
(€ \text { Million }) \\
\end{array}$ & $\begin{array}{r}\text { Price } \\
(€ / \text { kg. })\end{array}$ & $\begin{array}{l}\text { Self-suffi- } \\
\text { ciency (\%) }\end{array}$ \\
\hline Cod & 632,000 & 1,011 & 1.60 & 84 & 436,000 & 620 & 1.42 & 52 \\
\hline Haddock & 165,000 & 196 & 1.19 & 100 & 76,000 & 87 & 1.15 & 82 \\
\hline Saithe & 225,000 & 146 & 0.65 & 99 & 99,000 & 43 & 0.43 & 100 \\
\hline Pollack & 10,000 & 21 & 2.19 & 100 & 525,000 & 338 & 0.64 & 0 \\
\hline Hake & 125,000 & 466 & 3.74 & 72 & 434,000 & 883 & 2.03 & 2 \\
\hline Whiting & 49,000 & 51 & 1.03 & 100 & 1,000 & 1 & 1.08 & 100 \\
\hline Blue whiting & 5,000 & 5 & 1.03 & 100 & 7,000 & 2 & 0.33 & 100 \\
\hline Freshwater fish & 3,000 & 10 & 3.16 & 0 & 83,000 & 115 & 1.40 & 0 \\
\hline Megrim & 6,000 & 19 & 3.02 & 95 & 0 & 0 & 1.63 & 0 \\
\hline Monkfish & 7,000 & 31 & 4.26 & 81 & 16,000 & 56 & 3.50 & 0 \\
\hline Sole & 37,000 & 322 & 8.77 & 99 & 6,000 & 15 & 2.48 & 20 \\
\hline Plaice & & . & . & - & 102,000 & 182 & 1.78 & 98 \\
\hline Lemon sole & 11,000 & 36 & 3.37 & 100 & 0 & 0 & 2.25 & 0 \\
\hline Turbot & 4,000 & 34 & 8.93 & 100 & 0 & 0 & 19.48 & 0 \\
\hline Dab & 11,000 & 12 & 1.12 & 100 & 0 & 0 & 2.20 & 0 \\
\hline Rays & 9,000 & 15 & 1.69 & 100 & 1,000 & 1 & 1.27 & 100 \\
\hline Herring & 887,000 & 271 & 0.31 & 100 & 185,000 & 78 & 0.42 & 100 \\
\hline Mackerel & 473,000 & 328 & 0.69 & 100 & 82,000 & 56 & 0.68 & 91 \\
\hline Anchovies & 109,000 & 177 & 1.62 & 98 & 2,000 & 2 & 0.78 & 0 \\
\hline Salmon & 395,000 & 1,243 & 3.15 & 100 & 103,000 & 203 & 1.97 & 50 \\
\hline Swordfish & 11,000 & 75 & 6.78 & 87 & 25,000 & 90 & 3.67 & 49 \\
\hline Norway lobster & 43,000 & 268 & 6.29 & 100 & 1,000 & 14 & 11.38 & 79 \\
\hline Shrimp & 109,000 & 105 & 0.96 & 91 & 317,000 & 1,738 & 5.48 & 3 \\
\hline Total & $3,326,000$ & 4,842 & 1.46 & 93 & $2,501,000$ & 4,524 & 1.81 & 22 \\
\hline
\end{tabular}

Source: Eurostat New Cronos Database, Ofimer (1999), Statistics Iceland (2006) and Statistics Faroe Islands (2006). 
TABLE 2. Model and rank determination.

\begin{tabular}{|c|c|c|c|c|c|c|c|c|}
\hline \multirow[t]{3}{*}{ Species } & \multirow[t]{3}{*}{ Model $^{1}$} & \multicolumn{6}{|c|}{ Johansen tests } & \multirow{3}{*}{$\begin{array}{l}\text { Comp. } \\
\text { matrix }\end{array}$} \\
\hline & & \multicolumn{3}{|c|}{ Eigenvalues } & \multicolumn{3}{|c|}{ Trace test ${ }^{2}$} & \\
\hline & & 1 & 2 & 3 & 1 & 2 & 3 & \\
\hline \multicolumn{9}{|l|}{ Fresh: } \\
\hline 1. Cod-hake & $2 \mathrm{ND}_{1}$ & 0.14 & 0.02 & . & 21.96 & 2.59 & . & 0.69 \\
\hline 2. Cod-whiting & $1 \mathrm{SD}_{1}$ & 0.20 & 0.02 & . & 32.29 & 2.44 & . & 0.59 \\
\hline 3. Hake-sole-mackerel & $2 \mathrm{~N}$ & 0.34 & 0.13 & 0.05 & 79.80 & 25.26 & 7.40 & 0.66 \\
\hline 4. Hake-sole-N. lobster & $1 \mathrm{~N}$ & 0.19 & 0.15 & 0.05 & 54.93 & 27.92 & 6.46 & 0.67 \\
\hline 5. Hake-lemon sole & $1 \mathrm{SD}_{3} \mathrm{D}_{6}$ & 0.14 & 0.05 & . & 25.60 & 6.19 & . & 0.73 \\
\hline 6. Monkfish-l. sole-turbot & $1 \mathrm{SD}_{4} \mathrm{D}_{6}$ & 0.17 & 0.13 & 0.04 & 46.70 & 22.47 & 4.85 & 0.77 \\
\hline 7. Monkfish-lemon sole & $1 \mathrm{SD}_{6}$ & 0.13 & 0.03 & . & 22.24 & 4.57 & . & 0.77 \\
\hline 8. Sole-lemon sole & $2^{\mathrm{ND}}{ }_{6}$ & 0.16 & 0.05 & . & 28.89 & 6.36 & . & 0.60 \\
\hline 9. Herring-mackerel & $3 S$ & 0.15 & 0.03 & . & 25.28 & 4.30 & . & 0.63 \\
\hline 10. Herring-anchovies & $2 \mathrm{~S}$ & 0.14 & 0.06 & . & 26.77 & 7.77 & . & 0.72 \\
\hline 11. Herring-swordfish & $1 \mathrm{SD}_{7} \mathrm{D}_{10}$ & 0.12 & 0.04 & . & 22.16 & 5.23 & . & 0.74 \\
\hline 12. Anchovies-salmon & $3 \mathrm{SD}_{9}$ & 0.11 & 0.05 & . & 21.58 & 6.36 & . & 0.74 \\
\hline \multicolumn{9}{|l|}{ Frozen: } \\
\hline$\overline{\text { 13. Cod-haddock }}{ }^{3}$ & $3 N$ & 0.18 & 0.03 & . & 21.48 & 2.71 & . & 0.52 \\
\hline 14. Cod-hake ${ }^{3}$ & $2 \mathrm{~N}$ & 0.14 & 0.04 & . & 18.08 & 4.16 & . & 0.72 \\
\hline 15. Cod-plaice & $2 \mathrm{SD}_{11} \mathrm{D}_{13}$ & 0.11 & 0.04 & . & 19.31 & 4.76 & . & 0.77 \\
\hline 16. Pollack-plaice & $4 \mathrm{ND}_{12}$ & 0.15 & 0.04 & . & 26.35 & 5.13 & . & 0.52 \\
\hline 17. Hake-plaice & $2 \mathrm{~N}$ & 0.22 & 0.03 & . & 35.81 & 3.75 & . & 0.39 \\
\hline 18. Monkfish-plaice ${ }^{3}$ & $2 \mathrm{~N}$ & 0.33 & 0.03 & . & 40.27 & 3.01 & . & 0.46 \\
\hline 19. Plaice-herring & $4 \mathrm{ND}_{14}$ & 0.14 & 0.05 & . & 26.20 & 6.57 & . & 0.64 \\
\hline \multicolumn{9}{|l|}{ Fresh and frozen: } \\
\hline 20. Salmon & $3 \mathrm{ND}_{9} \mathrm{D}_{15}$ & 0.15 & 0.05 & . & 27.27 & 6.31 & . & 0.69 \\
\hline
\end{tabular}

Notes:

1. The number indicate the number of lags at which the estimations are undertaken, $\mathrm{S}=$ seasonal corrected by introducing 11 centred seasonal dummies, $\mathrm{N}=$ not seasonal corrected and $\mathrm{D}=$ dummy introduced to correct for outlier observations. $\mathrm{D}_{1}$ is for fresh cod (1995.05; 2000.01), $\mathrm{D}_{2}$ is for fresh cod (1995.05), $D_{3}$ is for fresh hake (2004.12 and 2005.01), $D_{4}$ is for fresh monkfish (1999.12 and 2000.01), $D_{5}$ is for fresh sole (1998.06), $D_{6}$ is for fresh lemon sole (2004.11), $D_{7}$ is for fresh herring (2005.03), $D_{8}$ is for fresh mackerel (1998.01), $\mathrm{D}_{9}$ is for fresh salmon (1999.10 and 1999.11), $\mathrm{D}_{10}$ is for fresh swordfish (1999.08 and 2002.01), $\mathrm{D}_{11}$ is for frozen cod (2000.01), $\mathrm{D}_{12}$ is for frozen plaice (2000.01), $\mathrm{D}_{13}$ is for frozen plaice (2001.05), $\mathrm{D}_{14}$ is for frozen herring (1999.04) and $\mathrm{D}_{15}$ is for frozen salmon (2001.09).

2. Bold measure $5 \%$ significance, according to critical values known from Johansen (1996).

3. Estimates are for the period 1998.01 to 2005.12. 
TABLE 3. Multivariate test for stationarity of price series, given rank n-1.

\begin{tabular}{|c|c|c|c|}
\hline & \multicolumn{3}{|c|}{ Species $^{1}$} \\
\hline & First & Second & Third \\
\hline \multicolumn{4}{|l|}{ Fresh: } \\
\hline$\overline{1 . \text { Cod-hake }}$ & $16.68(<0.01)$ & $9.51(<0.01)$ & . \\
\hline 2. Cod-whiting & $27.41(<0.01)$ & $19.69(<0.01)$ & . \\
\hline 3. Hake-sole-mackerel & $7.91(<0.01)$ & $7.97(<0.01)$ & $10.38(<0.01)$ \\
\hline 4. Hake-sole-N. lobster & $8.39(<0.01)$ & $12.69(<0.01)$ & $10.72(<0.01)$ \\
\hline 5. Hake-lemon sole & $6.30(0.01)$ & $12.14(<0.01)$ & . \\
\hline 6. Monkfish-l. sole-turbot & $12.43(<0.01)$ & $10.48(<0.01)$ & $4.47(0.04)$ \\
\hline 7. Monkfish-lemon sole & $12.84(0.01)$ & $10.47(<0.01)$ & . \\
\hline 8. Sole-lemon sole & $13.06(<0.01)$ & $8.96(<0.01)$ & . \\
\hline 9. Herring-mackerel & $14.16(<0.01)$ & $13.73(<0.01)$ & . \\
\hline 10. Herring-anchovies & $9.13(<0.01)$ & $4.20(0.04)$ & . \\
\hline 11. Herring-swordfish & $7.53(<0.01)$ & $9.45(<0.01)$ & . \\
\hline 12. Anchovies-salmon & $7.84(<0.01)$ & $5.17(0.02)$ & . \\
\hline \multicolumn{4}{|l|}{ Frozen: } \\
\hline$\overline{\text { 13. Cod-haddock }}$ & $11.56(<0.01)$ & $16.06(<0.01)$ & . \\
\hline 14. Cod-hake & $5.12(0.02)$ & $8.16(<0.01)$ & . \\
\hline 15. Cod-plaice & $9.66(<0.01)$ & $3.73(0.05)$ & \\
\hline 16. Pollack-plaice & $16.04(<0.01)$ & $4.54(0.03)$ & . \\
\hline 17. Hake-plaice & $28.00(<0.01)$ & $4.56(0.03)$ & . \\
\hline 18. Monkfish-plaice & $33.21(<0.01)$ & $4.40(0.04)$ & . \\
\hline 19. Plaice-herring & $3.71(0.05)$ & $13.06(<0.01)$ & . \\
\hline \multicolumn{4}{|l|}{ Fresh and frozen: } \\
\hline$\overline{\text { 20. Salmon }}$ & $10.74(<0.01)$ & $13.80(<0.01)$ & . \\
\hline
\end{tabular}

\section{Note:}

1. Stationarity is tested by imposing zero column restrictions on $\beta^{\prime}$ for other variables than the one tested for stationarity. For a model with three price series and a rank of two, like model 3, stationarity of the first of three variables is a test of $\beta^{\prime}=\left[\begin{array}{lll}1 & 0 & 0 \\ 0 & 0 & 0\end{array}\right]$. 
TABLE 4. Test for Law of One Price and weak exogeneity given rank n-1 ${ }^{1}$.

\begin{tabular}{|c|c|c|c|c|}
\hline & \multirow[t]{2}{*}{ Test LOP ${ }^{2}$} & \multicolumn{3}{|c|}{ Weak exogeneity ${ }^{3}$} \\
\hline & & First & Second & Third \\
\hline \multicolumn{5}{|l|}{ Fresh: } \\
\hline$\overline{\text { 1. Cod-hake }}$ & $15.47(<0.01)$ & $0.01(0.94)$ & $15.79(<0.01)$ & . \\
\hline 2. Cod-whiting & $8.87(<0.01)$ & $0.92(<0.01)$ & $25.04(<0.01)$ & \\
\hline 3. Hake-sole-mackerel & $12.34(<0.01)$ & $16.83(<0.01)$ & $1.88(0.39)$ & $36.43(<0.01)$ \\
\hline 4. Hake-sole-N. lobster & $9.87(<0.01)$ & $20.06(<0.01)$ & $2.55(0.28)$ & $11.10(<0.01)$ \\
\hline 5. Hake-lemon sole & $6.45(0.01)$ & $9.82(<0.01)$ & $2.24(0.14)$ & \\
\hline 6. Monkfish-l. sole-turbot & $12.81(<0.01)$ & $0.16(0.93)$ & $8.33(0.02)$ & $16.51(<0.01)$ \\
\hline 7. Monkfish-lemon sole & $1.56(0.21)$ & $0.01(0.95)$ & $8.76(<0.01)$ & 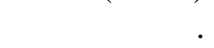 \\
\hline 8. Sole-lemon sole & $0.18(0.67)$ & $8.78(<0.01)$ & $5.26(0.02)$ & . \\
\hline 9. Herring-mackerel & $0.01(0.91)$ & $6.54(0.01)$ & $12.08(<0.01)$ & . \\
\hline 10. Herring-anchovies & $3.75(0.05)$ & $6.99(<0.01)$ & $5.23(0.02)$ & . \\
\hline 11. Herring-swordfish & $1.26(0.26)$ & $7.91(<0.01)$ & $4.91(0.03)$ & . \\
\hline 12. Anchovies-salmon & $8.29(<0.01)$ & $1.84(0.18)$ & $8.04(<0.01)$ & . \\
\hline \multicolumn{5}{|l|}{ Frozen: } \\
\hline 13. Cod-haddock & $15.06(<0.01)$ & $12.42(0.01)$ & $0.08(0.77)$ & . \\
\hline 14. Cod-hake & $9.51(<0.01)$ & $7.54(<0.01)$ & $3.48(0.06)$ & . \\
\hline 15. Cod-plaice & $2.30(0.09)$ & $0.99(0.32)$ & $8.48(<0.01)$ & . \\
\hline 16. Pollack-plaice & $12.84(<0.01)$ & $0.00(0.98)$ & $15.82(<0.01)$ & . \\
\hline 17. Hake-plaice & $21.85(<0.01)$ & $0.52(0.47)$ & $21.53(<0.01)$ & . \\
\hline 18. Monkfish-plaice & $33.54(<0.01)$ & $1.16(0.28)$ & $34.23(<0.01)$ & . \\
\hline 19. Plaice-herring & $11.06(<0.01)$ & $12.84(<0.01)$ & $0.04(0.84)$ & . \\
\hline \multicolumn{5}{|l|}{ Fresh and frozen: } \\
\hline 20. Salmon & $1.83(0.18)$ & $7.46(<0.01)$ & $6.89(<0.01)$ & . \\
\hline
\end{tabular}

Note:

1. Bold measure $5 \%$ significance.

2. The LOP is tested by imposing restrictions on the $\beta$-matrix where column sums to zero. For a model with three price series and a rank of two, like model 3, the LOP is a test of $\beta^{\prime}=\left[\begin{array}{ccc}1 & -1 & 0 \\ 1 & 0 & -1\end{array}\right]$.

3. Weak exogeneity is tested by imposing zero rows in $\alpha$. For a model with three price series and a rank of two, like model 3, weak exogeneity of the first price series is a test of $\alpha=\left[\begin{array}{cc}0 & 0 \\ \alpha_{21} & \alpha_{22} \\ \alpha_{31} & \alpha_{32}\end{array}\right]$. 
TABLE 5. The long run impact matrix of the moving average representation, given rank $\mathbf{n}-\mathbf{1}^{1}$.

\begin{tabular}{lrrrrrrrrr}
\hline & $\mathrm{C}_{11}$ & $\mathrm{C}_{12}$ & $\mathrm{C}_{13}$ & $\mathrm{C}_{21}$ & $\mathrm{C}_{22}$ & $\mathrm{C}_{23}$ & $\mathrm{C}_{31}$ & $\mathrm{C}_{32}$ & $\mathrm{C}_{33}$ \\
\hline Fresh: & & & & & & & & & \\
1. Cod-hake & $\mathbf{0 . 8 0}$ & 0.01 &. & $\mathbf{0 . 1 9}$ & 0.00 &. &. &. &. \\
2. Cod-whiting & $\mathbf{1 . 0 5}$ & -0.07 &. & $\mathbf{0 . 7 3}$ & -0.05 &. &. &. &. \\
3. Hake-sole-mackerel & $\mathbf{0 . 2 1}$ & $\mathbf{0 . 3 4}$ & 0.03 & $\mathbf{0 . 3 9}$ & $\mathbf{0 . 6 3}$ & 0.05 & $\mathbf{0 . 7 5}$ & $\mathbf{1 . 2 3}$ & 0.09 \\
4. Hake-sole-N. lobster & -0.02 & $\mathbf{0 . 3 0}$ & $\mathbf{0 . 1 1}$ & -0.05 & $\mathbf{0 . 7 5}$ & $\mathbf{0 . 2 8}$ & -0.05 & $\mathbf{0 . 7 2}$ & $\mathbf{0 . 2 7}$ \\
5. Hake-lemon sole & $\mathbf{0 . 2 0}$ & $\mathbf{0 . 2 8}$ &. & $\mathbf{0 . 5 6}$ & $\mathbf{0 . 8 1}$ &. &. &. &. \\
6. Monkfish-l. sole-turbot & $\mathbf{0 . 9 5}$ & 0.04 & 0.07 & $\mathbf{0 . 7 7}$ & 0.03 & 0.06 & $\mathbf{0 . 2 8}$ & 0.01 & 0.02 \\
7. Monkfish-lemon sole & $\mathbf{0 . 9 8}$ & 0.02 &. & $\mathbf{0 . 7 9}$ & 0.02 &. &. &. &. \\
8. Sole-lemon sole & $\mathbf{0 . 5 2}$ & $\mathbf{0 . 4 4}$ &. & $\mathbf{0 . 6 0}$ & $\mathbf{0 . 5 1}$ &. &. &. &. \\
9. Herring-mackerel & $\mathbf{0 . 4 4}$ & $\mathbf{0 . 3 0}$ &. & $\mathbf{0 . 4 5}$ & $\mathbf{0 . 3 0}$ &. &. &. &. \\
10. Herring-anchovies & $\mathbf{0 . 5 0}$ & $\mathbf{0 . 7 8}$ &. & $\mathbf{0 . 1 7}$ & $\mathbf{0 . 2 7}$ &. &. &. &. \\
11. Herring-swordfish & $\mathbf{0 . 4 1}$ & $\mathbf{0 . 9 3}$ &. & $\mathbf{0 . 2 6}$ & $\mathbf{0 . 5 9}$ &. &. &. &. \\
12. Anchovies-salmon & $\mathbf{0 . 7 7}$ & $\mathbf{- 0 . 1 4}$ &. & $\mathbf{- 0 . 8 2}$ & $\mathbf{0 . 1 5}$ &. &. &. &.
\end{tabular}

\section{Frozen:}

13. Cod-haddock

14. Cod-hake

$\begin{array}{rrrrr}0.02 & \mathbf{0 . 2 0} & . & 0.07 & \mathbf{0 . 6 5} \\ \mathbf{0 . 1 8} & -\mathbf{0 . 4 5} & . & \mathbf{- 0 . 2 1} & \mathbf{0 . 5 4} \\ \mathbf{0 . 7 0} & 0.23 & . & \mathbf{0 . 3 5} & 0.11 \\ \mathbf{1 . 0 1} & 0.00 & . & \mathbf{0 . 2 7} & 0.00 \\ \mathbf{0 . 7 8} & -0.05 & . & \mathbf{0 . 1 9} & -0.01 \\ \mathbf{0 . 7 8} & -0.15 & . & \mathbf{- 0 . 1 0} & 0.01 \\ -0.02 & \mathbf{0 . 1 5} & . & -0.08 & \mathbf{0 . 7 0}\end{array}$

15. Cod-plaice

16. Pollack-plaice

17. Hake-plaice

18. Monkfish-plaice

19. Plaice-herring

$-0.02 \quad \mathbf{0 . 1 5}$

$0.33 \quad 0.35$

$0.45 \quad 0.47$

Fresh and frozen:

20. Salmon

Note: 1 . The moving average representations are identified without restrictions on $\alpha$ and $\beta$. Significant coefficients with t-ratios larger than 1.8 are bold. 
FIGURE 1. Selected market integration between dominant species.

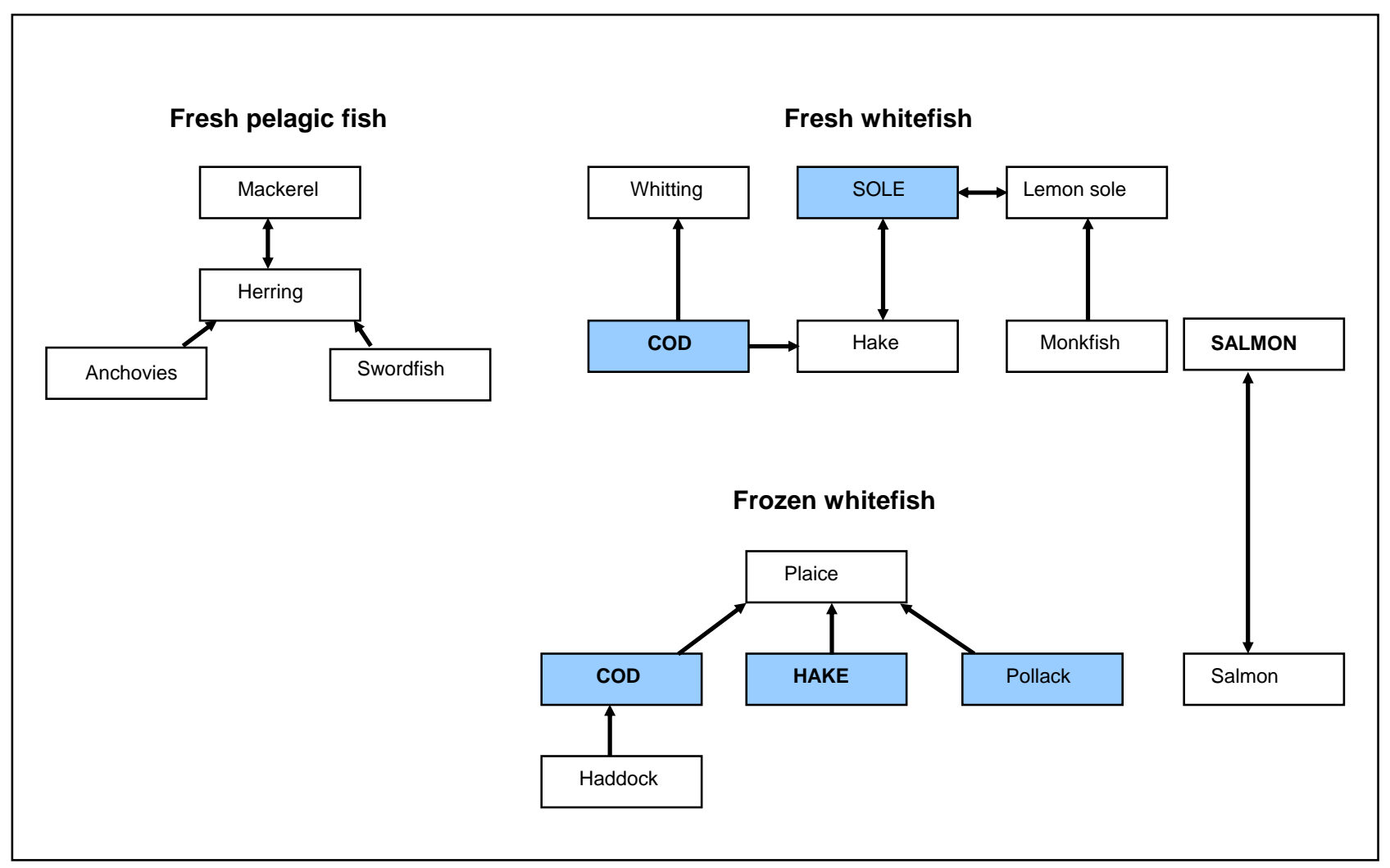


APPENDIX 1. Segments.

\begin{tabular}{|c|c|c|c|}
\hline Criteria & Segment & Fresh & Frozen \\
\hline \multirow[t]{4}{*}{ 1. Species } & Whitefish & Cod, haddock, saithe, hake (whiting) & $\begin{array}{l}\text { Cod, pollack, hake, freshwater fish } \\
\text { (haddock, saithe) }\end{array}$ \\
\hline & Flatfish & Monkfish, sole, lemon sole, turbot & Monkfish, plaice \\
\hline & Pelagic fish & $\begin{array}{l}\text { Herring, mackerel, salmon, } \\
\text { anchovies (swordfish) }\end{array}$ & Herring, salmon, swordfish, mackerel \\
\hline & Crustaceans & Norway lobster, shrimp & . \\
\hline \multirow[t]{2}{*}{ 2. Colour } & White & Cod, hake, sole, mackerel (herring) & $\begin{array}{l}\text { Cod, pollack, hake, plaice (freshwater } \\
\text { fish) }\end{array}$ \\
\hline & Non-white & $\begin{array}{l}\text { Saithe, Norway lobster, shrimp, } \\
\text { salmon }\end{array}$ & Saithe, shrimp, salmon \\
\hline \multirow[t]{2}{*}{ 3. Size } & $\begin{array}{l}\text { Small } \\
\text { Medium }\end{array}$ & $\begin{array}{l}\text { Sole, herring, mackerel, anchovies } \\
\text { Cod, haddock, saithe hake (whiting) }\end{array}$ & $\begin{array}{l}\text { Plaice, herring, mackerel } \\
\text { Cod, pollack, hake, freshwater fish } \\
\text { (haddock, saithe) }\end{array}$ \\
\hline & Large & Monkfisk, salmon, swordfish & Monkfish, salmon, swordfish \\
\hline \multirow[t]{6}{*}{ 4. Price } & 1 (low) & Saithe, mackerel & Herring, saithe \\
\hline & 2 & Shrimp, saithe, haddock & Pollack, mackerel \\
\hline & 3 & Cod, anchovies & Haddock, freshwater fish, cod, plaice \\
\hline & 4 & Salmon, lemon sole, hake, monkfish & Hake, plaice, salmon \\
\hline & 5 & Norway lobster, swordfish & Monkfish, swordfish \\
\hline & 6 & Sole, swordfish, turbot & \\
\hline \multirow[t]{2}{*}{ 5. Fat } & Lean $(=<5 \mathrm{~g})$ & $\begin{array}{l}\text { Cod, hake, sole, Norway lobster } \\
\text { (haddock, saithe) }\end{array}$ & $\begin{array}{l}\text { Cod, pollack, hake, shrimp (plaice, } \\
\text { freshwater fish) }\end{array}$ \\
\hline & Fat $(>5 \mathrm{~g})$ & $\begin{array}{l}\text { Herring, mackerel, } \\
\text { anchovies }\end{array}$ & Herring, mackerel, salmon \\
\hline
\end{tabular}




\section{Notes}

${ }^{1}$ The relative stability principle is the founding element of the Common Fisheries Policy. It states that each member states share of the total allowable catch of each fish stock in Community waters is fixed.

${ }^{2}$ To qualify the results of the trace test, other rank indicators such as graphs of the co-integrating relations, characteristics roots, number of column in the $\alpha$ matrix with significant parameters and economic interpretability are also examined.

${ }^{3}$ See Kinnucan and Myrland (2002) for more information on the EU anti-dumping complaints against Norwegian salmon and the agreement between EU and Norway which ran in the 1997-2003 period.

${ }^{4}$ Eurostat (2007) report a total catch of fish on 13.7 Million tonnes of which approximately 3.5 Million tonnes were used for fishmeal and oil (non-human consumption).

${ }^{5}$ This number is a low estimate since foreign trade is measured in traded weight like gutted and filleted.

${ }^{6}$ Total import into Norway, Iceland and the Faroe Islands is included in the data to the extent that it is performed as foreign landings. Furthermore, supply includes all products which are at European land at some stages in the products live time, i.e. also if it is exported later on.

${ }^{7}$ Since quotas do not exist in the Mediterranean Sea for any of the species included in the analysis, landings originating there are only included in the analysis if the species are also caught in other fisheries subject to quotas.

${ }^{8}$ Whitefish consist of cod and similar species regarding being round, white and bottom living. The species are cod, haddock, saithe, pollack, hake, whiting and freshwater fish. The size of the fish is subjectively assessed on average at the time of final sale and may, therefore, not necessarily follow official classifications. The species are chosen to cover in a way so each species is tested in relation to other species with price levels on $+/-25 \%$ of its price.

${ }^{9}$ The 20 well-specified models reveal market integration. The remaining models only reveal that market integration could not be found in well-specified models with price variables integrated of order one included. The common characteristics of these models are that market integration remain unproven.

${ }^{10}$ The results of the misspecification tests are not reported due to space limitations, but results are available form the authors on request.

${ }^{11}$ A restricted constant model is used as opposed to a restricted trend model, since only a form of market integration where relative prices are constant are sought in the present paper.

${ }^{12}$ These results were obtained using a $5 \%$ significance level in all models except in 14 and 15 of frozen cod and hake and plaice respectively. These models were only accepted at the $10 \%$ level. A rank of one in model 14 and 15 are further accepted, since the significance of the $\alpha$ parameters in each cointegrating vector and the graphs of the cointegrating relations point towards a rank of one. 